\title{
Editorial
}

\section{Urban and Rural Event Tourism and Sustainability: Exploring Economic, Social and Environmental Impacts}

\author{
Nicholas Wise \\ Liverpool Business School, Liverpool John Moores University, 4/6 Rodney Street, Liverpool L1 2TZ, UK; \\ n.a.wise@ljmu.ac.uk or nwise5@kent.edu; Tel.: +44-(0)-98-184-9174
}

Received: 12 July 2020; Accepted: 14 July 2020; Published: 16 July 2020

\begin{abstract}
This Special Issue on "Urban and Rural Event Tourism and Sustainability: Exploring Economic, Social and Environmental Impacts" brings together eight papers. The papers focus specifically on either economic, social or environmental impacts or consider practical and conceptual overlaps across different impacts. In this collection, authors offer perspective on pressing issues concerning urban and rural tourism planning, policy and development aligned with economic, social and/or environmental impacts. The papers also outline how different approaches and contexts of urban and rural event tourism regeneration, planning and development are considered in relation to the triple bottom line as well as assess how the triple bottom line is considered when planning for sustainable event tourism futures and legacies in cities. This collection of papers aims to present new theoretical insight, perspective and/or recommendations that address further considerations and directions for urban event tourism research, concerning sustainability, policy, development and regeneration. This editorial introduces some directions and references to direct readers interested in this topical area of research going forward.
\end{abstract}

Keywords: event tourism; sustainability; triple bottom line; economic impacts; social impacts; environmental impacts; legacy planning; planning and development; urban and rural change; regeneration

\section{Overview of the Special Issue Theme}

Event tourism is a growing field of study that connects scholars and practitioners [1,2]. As indicated by the review papers in this Special Issue [3] and in earlier published work [4], a wide range of impacts are created and bring together these economic, social and environmental impacts which papers included in this Special Issue explore. This Special Issue focuses on sustainability and event tourism in urban and rural areas. The triple bottom line is a framework to evaluate events and tourism; addressing economic, social and environmental impacts [5-7]. The purpose of this Special Issue is to build on current debased and understandings; challenge and critique perspectives and pressing issues concerning urban and rural event tourism planning; and review policy and development, specifically in relation to sustainability strategies as highlighted in recent edited book collections [8,9], as places and destinations seek to increase awareness and competitiveness [10,11].

Triple bottom line approaches are widely recognised by scholars, educators, planners, policy makers and business operators. This is especially important when considering events and tourism, as stakeholders need to carefully and critically address sustainability agendas when planning for the future or urban/rural legacies [12,13]. While notions of people, profit and planet are important to practically and conceptually outline, as argued and coined by John Elkington, it is important to reflect on the recent literature and case examples that emphasize different contexts of sustainability, 
as there is a need to rethink and reconsider this concept from different disciplinary perspectives [14,15]. While sustainability is often regarded as a term that looks at the environment and financial growth, researchers are increasingly focusing on social impacts and new opportunities that emerge such as new enterprises, volunteering, education and training, and place/community pride, as they affect residents and local society.

Accepted are three key areas of focus when exploring triple bottom line concepts: economic, social and environmental responsibilities, often also referred to as the three Ps (people, profit and planet). As core pillars of sustainability [16], it is key for event tourism destinations and planners to react to these to also enhance image, competitiveness and sustainable destination management. Much scholarship, when addressing sustainability, considers environmental impacts and management $[17,18]$. Economic sustainability is ever-pressing, especially as competition to attract tourists, consumers and new clientele bases is increasing and thus destinations need to host events or display tourism products that are up-to-date and meet current demands $[19,20]$. However, there is increased emphasis on social and community impacts, perhaps as these are intangible impacts that relate to local attitudes about places as well as quality of life for residents and businesses in destinations [21-25], especially as places continually change and transform-which then calls for new forms of participation $[26,27]$ and ways of evaluating social impacts [28].

Given the range of work in this area to draw upon, and building on collections of the guest editor $[21,29,30]$, this Special Issue welcomed papers that:

- Offer perspective on pressing issues concerning urban and rural tourism planning, policy and development aligned with economic, social and/or environmental impacts;

- Outline how different approaches and contexts of urban and rural event tourism regeneration, planning and development are considered in relation to the triple bottom line;

- Assess how the triple bottom line is considered when planning for sustainable event tourism futures and legacies in cities.

This Special Issue aims to present new theoretical insight, perspective and/or recommendations that address further considerations and directions for urban event tourism research, concerning sustainability, policy, development and regeneration.

\section{Overview of Papers in This Special Issue}

The Special Issue builds around the points noted above and was also open to proposals that related to or challenge understandings of urban and rural event tourism and sustainability. Eight papers are included in this Special Issue, each focusing on critical issues and cases from different regions of the world. Taking more of an economic impact approach in the paper: "Asymmetric Impact of Institutional Quality on Tourism Inflows Among Selected Asian Pacific Countries" authors Muhammad Asif Khan, József Popp, Mirza Nouman Ali Talib, Zoltán Lakner, Muhammad Atif Khan and Judit Oláh focus on national and regional tourism through anticipated sustainable economic benefits. They argue for the need to optimize desired incentives to stimulate tourism flows in the Asia Pacific region. Focusing on another case in Asia, the paper: "Carbon Footprint Evaluation of the Business Event Sector in Japan" by Yusuke Kitamura, Selim Karkour, Yuki Ichisugi and Norihiro Itsubo, frames how the business event sector seeks substantial economic impact, looking at Meetings, Incentives, Conferences and Exhibition (MICE) events in particular, but focus on environmental impacts. The authors consider MICE sustainability agendas, some guidelines for MICE sustainability and consider carbon management so that future studies can further calculate environmental impacts and sustainability.

Fulfilling the focus of different impacts and looking at particular overlaps, Marko Perić and Vanja Vitezić, authors of "Socio-Economic Impacts of Event Failure: The Case of a Cancelled International Cycling Race" are concerned with the organization of large-scale sporting events, and how they provide different benefits and costs for hosting communities. The next paper again focuses on cases in Europe. "Barriers to Stakeholder Involvement in Sustainable Rural Tourism Development—Experiences from 
Southeast Europe" by Alice Wanner and Ulrike Pröbstl-Haider considers participative planning approaches and how this is especially vital to sustainable development in rural areas, a critical area highlighted in earlier work in the journal [31]. Adding to the body of knowledge in this area, the authors argue that there are many issues and barriers facing stakeholder involvement, and this causes problems as it alters perceptions of sustainability and creates conflicts of interest, as they argue, for a participative planning approach among stakeholders.

Another paper that considers the environment from the standpoint of green behaviours is "Convention Tourism and Sustainability: Exploring Influencing Factors on Delegate Green Behavior That Reduce Environmental Impacts" by Heesup Han, Soyeun Lee, Amr Al-Ansi, Hyeon-Cheol Kim, Hyungseo Bobby Ryu, Jinkyung Jenny Kim and Wansoo Kim, which also focuses on the convention tourism industry. The authors focus on green attitudes, social norms, eco-concern, and personal moral obligations, and how this relates to how event delegates intend to, or do, practice conservation behaviours. "Human-Leopard (Panthera pardus fusca) Co-Existence in Jhalana Forest Reserve, India" by Swapnil Kumbhojkar, Reuven Yosef, Yanina Benedetti and Federico Morelli is concerned with the encroachment of human activities on wilderness areas, offering another destination focused on environmental impacts.

The paper "Point Cloud-Oriented Inspection of Old Street's Sustainable Transformation from the Ceramic Industry to Cultural Tourism: A Case Study of Yingge, a Ceramic Town in Taiwan" by Naai-Jung Shih, Wen-Tse Hsu and Pei-Huang Diao considers changing impacts over time in Yingge (a ceramic-producing town in Northern Taiwan). From several conceptual and practical points of focus, the authors consider historical background, government planning strategies, commercial activities, cultural identity, and living patterns in the town. The final paper is a review paper, "Assessing and Considering the Wider Impacts of Sport-Tourism Events: A Research Agenda Review of Sustainability and Strategic Planning Elements", where Ana Kersulić, Marko Perić and Nicholas Wise highlight existing literature published in this field of study by examining papers referenced in the Web of Science Core Collection (WoSCC) database focusing primarily on the impacts and legacy of sports events, strategic planning elements, and attributes necessary for achieving sustainability.

\section{Going Forward}

Going forward, it is acknowledged that more work can build on the social impacts of events on destinations [32-34]. It is especially important to focus on cases in emerging economy countries [7,35]. These impacts are also important to consider in relation to wider urban and regional regeneration strategies whereby planning and stakeholder collaborations and management play a key role going forward [8,36], over the long-term [37], and as destinations expand event portfolios [38] or link events alongside destination development $[39,40]$.

Author Contributions: N.W. wrote the editorial and acted as guest editor for this Special Issue. Author has read and agreed to the published version of the manuscript.

Funding: This research received no external funding.

Conflicts of Interest: The author declares no conflict of interest.

\section{References}

1. Getz, D. Event tourism: Definition, evolution, and research. Tour. Manag. 2008, 29, 403-428. [CrossRef]

2. Jago, L.; Chalip, L.; Brown, G.; Mules, T.; Ali, S. Building Events into Destination Branding: Insights from Experts. Event Manag. 2003, 8, 3-14. [CrossRef]

3. Kersulić, A.; Perić, M.; Wise, N. Assessing and Considering the Wider Impacts of Sport-Tourism Events: A Research Agenda Review of Sustainability and Strategic Planning Elements. Sustainability 2020, 12, 4473. [CrossRef]

4. Getz, D.; Page, S.J. Progress and prospects for event tourism research. Tour. Manag. 2016, 52, 593-631. [CrossRef] 
5. AlBalushi, A.A.; Wise, N. Planning for Tourism in Oman based on Lessons from Dubai: Overviewing Economic, Environmental and Socio-Cultural Impacts. In Tourism in the Arab World: An Industry Perspective; Almuhrzi, H., Alriyami, H., Scott, N., Eds.; Channel View Publications: Bristol, UK, 2017; pp. 87-103.

6. Dwyer, L. Relevance of triple bottom line reporting to achievement of sustainable tourism: A scoping study. Tour. Rev. Int. 2005, 9, 79-93. [CrossRef]

7. Wise, N. Eventful futures and triple bottom line impacts: BRICS, image regeneration and competitiveness. J. Place Manag. Dev. 2019, 13, 89-100. [CrossRef]

8. Wise, N.; Harris, J. (Eds.) Sport, Events, Tourism and Regeneration; Routledge: London, UK, 2017.

9. Wise, N.; Harris, J. (Eds.) Events, Places and Societies; Routledge: London, UK, 2019.

10. Aquilino, L.; Armenski, T.; Wise, N. Assessing the competitiveness of Matera and the Basilicata Region (Italy) ahead of the 2019 European Capital of Culture. Tour. Hosp. Res. 2019, 19, 503-517. [CrossRef]

11. Aquilino, L.; Wise, N. Evaluating the Competitiveness of the Northern and Southern Macro-Regions of Italy. AlmaTourism 2016, 7, 23-47.

12. Wise, N.; Hall, G. Transforming Brazil: Sporting mega-events, tourism, geography and the need for sustainable regeneration in host cities. In Sport, Events, Tourism and Regeneration; Wise, N., Harris, J., Eds.; Routledge: London, UK, 2017; pp. 24-39.

13. Wise, N.; Perić, M.; Đurkin, J. Benchmarking Service Delivery for Sports Tourism and Events: Lessons for Gorski kotar, Croatia from Pokljuka, Slovenia. Eur. J. Tour. Res. 2019, 22, 107-128.

14. Henriques, A.; Richardson, J. (Eds.) The Triple Bottom Line: Does It All Add Up? Routledge: London, UK, 2004.

15. Wise, N. Outlining triple bottom line contexts in urban tourism regeneration. Cities 2016, 53, 30-34. [CrossRef]

16. Fairley, S.; Tyler, B.D.; Kellett, P.; D’Elia, K. The Formula One Australian Grand Prix: Exploring the triple bottom line. Sport. Man. Rev. 2011, 14, 141-152. [CrossRef]

17. Maguire, K.; Hanrahan, J. Local authority provision of environmental planning guidelines for event Management in Ireland. Eur. J. Tour. Res. 2016, 12, 54-81.

18. Yuan, Y.Y. Adding environmental sustainability to the management of event tourism. Int. J. Cult. Tour. Hosp. Res. 2013, 7, 175-183. [CrossRef]

19. Maguire, K. Examining the role of local authorities in planning for socio-economic event impacts. Local Econ. 2019, 34, 657-679. [CrossRef]

20. Maguire, K.; Hanrahan, J. Assessing the economic impact of event management in Ireland: A local authority planning perspective. Event Man. 2017, 21, 333-346. [CrossRef]

21. Hall, G.; Wise, N. Introduction: Sport and Social Transformation in Brazil. Bull. Latin Am. Res. 2019, 38, 265-266. [CrossRef]

22. Wise, N. Football on the Weekend: Rural Events and the Haitian Imagined Community in the Dominican Republic. In Exploring Community Festivals and Events; Jepson, A., Clarke, A., Eds.; Routledge: London, UK, 2015; pp. 106-117.

23. Wise, N. Editorial: Tourism and Social Regeneration. Soc. Sci. 2018, 7, 262. [CrossRef]

24. Wise, N. Towards a More Enabling Representation: Framing an Emergent Conceptual Approach to Measure Social Conditions Following Mega-Event Transformation in Manaus, Brazil. Bull. Latin Am. Res. 2019, 38, 300-316. [CrossRef]

25. Zhao, Y.; Wise, N. Evaluating the intersection between "green events" and sense of community at Liverpool's Lark Lane Farmers Market. J. Commun. Psychol. 2019, 47, 1118-1130. [CrossRef]

26. Clark, J.; Wise, N. (Eds.) Urban Renewal, Community and Participation: Theory, Policy and Practice; Springer: Berlin, Germany, 2018.

27. Wise, N.; Polidoro, M.; Hall, G.; Uvinha, R.R. User-Generated Insight of Rio's Rocinha Favela Tour: Authentic Attraction or Vulnerable Living Environment? Local Econ. 2019, 37, 680-698. [CrossRef]

28. Wise, N.; Perić, M. Sports tourism, regeneration and social impacts: New opportunities and directions for research, the case of Medulin, Croatia. In Tourism in the City: Towards and Integrative Agenda on Urban Tourism; Bellini, N., Pasquinelli, C., Eds.; Springer Vieweg: Berlin, Germany, 2017; pp. 311-320.

29. Wise, N. Editorial, Local community and local economy: Place, policies and power at the Micro-Scale. Local Econ. 2017, 32, 595-600. [CrossRef]

30. Wise, N.; Maguire, K. Editorial: Places, Practices and (Soft) Power. Local Econ. 2019, 34, 627-631. [CrossRef] 
31. Peric, M.; Đurkin, J.; Wise, N. Leveraging Small-Scale Sport Events: Challenges of Organising, Delivering and Managing Sustainable Outcomes in Rural Communities, the Case of Gorski kotar, Croatia. Sustainability 2016, 8, 1337. [CrossRef]

32. Liu, Y.-D. Socio-cultural impacts of major events: Evidence From the 2008 European Capital of Culture, Liverpool. Soc. Ind. Res. 2014, 115, 983-998. [CrossRef]

33. Richards, G.; de Brito, M.P.; Wilks, L. (Eds.) Exploring the Social Impacts of Events; Routledge: London, UK, 2013.

34. Wise, N.; Flinn, J.; Mulec, I. Exit Festival: Contesting political pasts, impacts on youth culture and regenerating the image of Serbia and Novi Sad. In Ideological, Social and Cultural Aspects of Events; Pernecky, T., Moufakkir, O., Eds.; CABI: Wallingford, UK, 2015; pp. 60-73.

35. Maharaj, B. The turn of the south? Social and economic impacts of mega-events in India, Brazil and South Africa. Local Econ. 2015, 30, 983-999. [CrossRef]

36. Richards, G.; Palmer, R. Eventful Cities: Cultural Management and Urban. Revitalisation; Butterworth-Heinemann: Oxford, UK, 2010.

37. Solberg, H.A.; Preuss, H. Major Sport Events and Long-Term Tourism Impacts. J. Sport Manag. 2007, 21, 213-234. [CrossRef]

38. Roche, M. Mega-Events and Modernity: Olympics and Expos in the Growth of Global Culture; Routledge: London, UK, 2000.

39. Wise, N.; Jimura, T. (Eds.) Tourism, Cultural Heritage and Urban. Regeneration: Changing Spaces in Historical Places; Springer: Berlin, Germany, 2020.

40. Fridriksson, J.; Wise, N.; Scott, P. Iceland's bourgeoning cruise industry: An economic opportunity or a local threat? Local Econ. 2020, 35, 143-154. [CrossRef]

(C) 2020 by the author. Licensee MDPI, Basel, Switzerland. This article is an open access article distributed under the terms and conditions of the Creative Commons Attribution (CC BY) license (http://creativecommons.org/licenses/by/4.0/). 